\title{
A Research on Brand Switching Factors of Millennial Customers on Toiletries
}

\author{
S. Nagarajan, A. Jafersadhiq
}

\begin{abstract}
Nowadays toiletries products became essential needs for individuals and there are almost 55 products come under toiletries with variety of categories like skin care, hair care, child care and body care. This study is to investigate the socioeconomic factors of the respondents, buying behavior of customer about toiletries and to investigate the factors that influence the customers when buying toiletries products and also to study the factors that make the millennial customers to switch from one brand to another brand in toiletries products. This study is conducted by survey method, over 100 millennial respondents were surveyed and various tests like percentage analysis, kruskal-wallis test and Friedman test were done. It is also found that the respondents will be loyal to the brand when the brand meets the satisfaction level of the respondents. And when it happens the respondents were ready to suggest the brand to others and influence them to try the brand.
\end{abstract}

\section{INTRODUCTION}

Toiletries products play an important role in our daily lives. Individual people are more conscious to up their standards of living in some ways. Now-a-days, with respect to this awareness, Toiletries product has already become nearly essential needs for individuals. Currently, over fifty five products are made covering a good vary of categories like

\begin{tabular}{|c|c|}
\hline $\begin{array}{l}\text { Skin care: } \\
\text { - } \quad \text { Skin } \\
\text { moisturizers } \\
\text { - } \quad \text { Body } \\
\text { creams } \\
\text { - } \quad \text { Body } \\
\text { lotions }\end{array}$ & 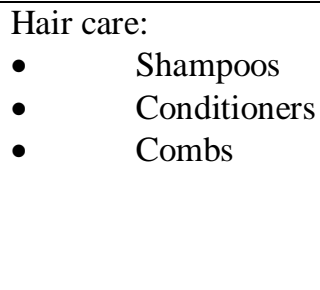 \\
\hline \begin{tabular}{ll}
\multicolumn{2}{l}{ Oral care: } \\
• & Tooth \\
brushes & \\
- & Tooth \\
pastes & \\
rinsers & \\
\end{tabular} & $\begin{array}{l}\text { Child care: } \\
\text { - } \quad \text { Powders } \\
\text { - } \quad \text { Baby soaps } \\
\text { - } \quad \text { Baby } \\
\text { moisturizers }\end{array}$ \\
\hline \begin{tabular}{|ll}
\multicolumn{2}{|l}{ Body care: } \\
- & Body \\
soaps & \\
- & Talcum \\
powder & \\
$\bullet$ & Lipstick \\
\end{tabular} & \\
\hline
\end{tabular}

These products were produced by numerous makers. Considering the importance of this study, I have attempted to explore the factors that influence consumer when shopping for Toiletries product from totally different marketers. This analysis tries to explore the factors that have an effect on individual customers in selecting their own Toiletries products. This analysis additionally tries to explore to spot the whole brand switching factors that have an effect on individual customers in deciding their Toiletries product.

\section{Brand Preferences}

People begin to form priorities at a really young age. Below any kind of product, most customers have completely different brands that embrace their own most well-liked choices. Once creating priorities, the primary goal of getting consumer priority teams is to extend the consumer preference to the group isn't a simple job to try and do. The definitions of name choices are "The Company chooses the brand rather than the product; the consumer doesn't need another brand." In every product class, customers have a lot of choices, extra information and better expectations than previously. To move customers on the road to priority, brands should gift their worth. While not a correct brand management strategy and goes down even at this level. Price, promotion and products convenience can greatly have an effect on our whole position within vary of client decisions.

If all matters are equal, customers ought to provide importance to a specific company quite the competitors. Brands are only possible by up the identity and importance of the marketplace for customers. The same whole activities that increase awareness can change priorities. Though awareness doesn't support the priorities alone, it improves the flexibility of seals to create and maintain untimely.

A great history and adequate investment and awareness are often achieved quickly. However, branding choices need your time and constant review. To realize the whole loyalty obtaining and sustaining preference is that the key purpose. Customers prefer a specific brand to come up with bigger revenues and to win the next share of the market and win the competition. Though current literatures of name preferences are exempting the model of personal changes from the model, several selling scholars acknowledge the consumer's importance in personal and chosen brand choices. McEnally and DeChernatony (1999) conclude that "integrating the brand's individual characteristics makes customers a lot of attractive, and that they are a lot of likely to join brands with

Revised Manuscript Received on September 14, 2019.

S. Nagarajan, Assistant Professor, School of Management Studies (SMS), Bannari Amman Institute of Technology, Sathyamangalam - 638 401, Tamilnadu, India.(E-mail: nagarajans@bitsathy.ac.in)

Dr. A. Jafersadhiq, Assistant Professor, Department of Management Studies, Erode Sengunthar Engineering College, Erode - 638057 , Tamilnadu, India. (E-mail: jaferm505@gmail.com) 


\section{A Research On Brand Switching Factors Of Millennial Customers On Toiletries}

desirable people."

Access and maintenance of priorities is a vital step in achieving brand loyalty. the flexibility to come up with higher returns, gain a lot of market share and win the competition may be a reward for a shopper a specific whole. The literature of name priorities typically depends on the model's temperament variables, and plenty of advertisers have the importance of brand selection and shopper domination within the choice of brand. McEnally and DeChernatony (1999) "Integrating a brand personal attributes that create customers a lot of attractive to join the brands with the desired roles".

\section{Brand Switching}

Brand switching occurs when the brand loyalty gets affected. Brand loyalty is nothing but when customers stick to a particular brand for years and he/she won't use other brands instead of their brand.

There are some factors that affect the brand loyalty:

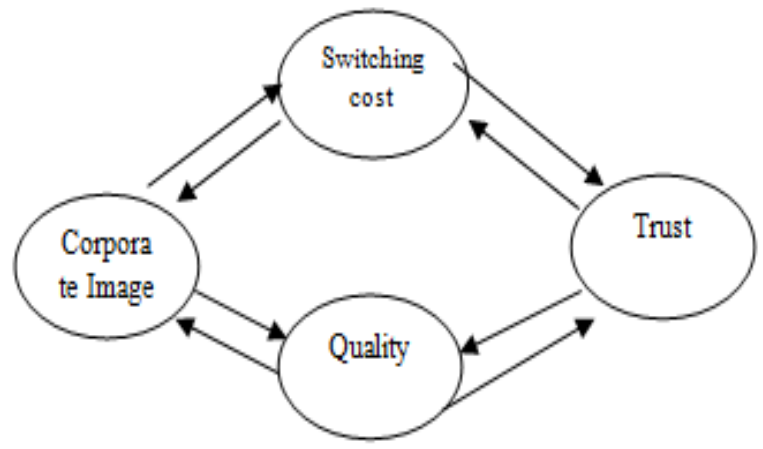

Fig. 1 Brand switching factors

- $\quad$ Corporate image

- $\quad$ Trust

- Quality

- $\quad$ Switching cost

Image: Branding is directly connected to the brand image, the brand image is the perception of the brand in the mindset of the customer, it can be perceived differently from one customer to another. It is easy to introduce a new product when a brand has a good image among the customers in the market. And it helps the marketer and customer relationship.

Trust: Trust is one of the important assets a company can gain in a business, it is a difficult task to develop a trust among the people and maintain the same trust for long time. It reflects the customer's expectation over the company to deliver a good product.

Quality: It is a difficult task to develop and maintain a trust among the customer in the market, for that a company should produce the product with high quality because the customer will look for is whether the product or service is worth full for the amount they've spent.

Switching cost: It is the cost that a customer should face when they decide to switch from one brand to another. If the switching cost is low then the chances of customer switching from one brand to another is high but when the switching cost is high then the customer will re-think the idea of switching from one brand to another.

\section{OBJECTIVES}

- To study the demographic factors of the customers. - To know the purchasing behavior of the customers.

- To investigate the influence level of peers, family members on buying products.

- To investigate the brand switching factors of the customers.

\section{SCOPE OF THE STUDY}

The research work concentrated on the analysis of consumer brand switching behavior of mobile phones. The scope of this study will cover the millennial customers, 100 people cannot be representative of the entire population but for maximum precision to be attained in this study, the customers of all age group who consumes toiletries would be studied. However, the findings of this study could be applied in the marketing of toiletries.

\section{REVIEW OF LITERATURE}

Babayev, Najaf. (2018) "Emotion-based marketing and its impact on consumer decision making". The requirement for this research is to think about the emotion-based marketing and its impact on consumer decision-making. The initial segment of this research depicts the idea of customer decision making. The accompanying segment speaks about customer decision making process. In the third segment of the article deals with factors that impact the decisionmaking process. The fourth part of the article described how emotional factors affect the decision-making process. The final part gives detail on the theoretical part and the clientbased emotional decision model.

Rieg, Denise Luciana ; Scramim, Fernando Cezar Leandro ; da Silva, Elaine Paola ; Rufino, Fabiana Alves (2018) "The Influence of the Seller's Performance on the Consumer Purchase Of Clothes and Personal Care, Toiletries and Cosmetics Products ".The objective of the research is to point out that, in both sectors, most respondents go to explicit stores to make their own buys. Price, seller performance, elegance, and brands are the main factors that influence consumers' decisions on which store to buy. They additionally found that the customer decisionmaking process and client loyalty are impacted by vendor performance. The parts of credibility, thoughtfulness regarding client needs, product information, affability and consideration aspects of the supplier's performance that respondents considered most significant in the two segments.

Senthilkumar, K (2018) "The Influence of Emotional Factors in the Purchase of Children Products and Brands". This investigation was directed in the Coimbatore region to discover the variables that influence the buying decision and found that age of the customers was influencing more on buying decisions; which means that when age increases that will increase the appropriateness of decision making or the quality of decision making. Individuals with moderate

Published By:

Blue Eyes Intelligence Engineering

\& Sciences Publication 
salaries are rational in decision about purchasing the kids' items. Generally speaking, the outcomes demonstrated that emotional factors have a greater influence than rational factors in the choice to purchase kid's items and brands. This implies the purchaser must know about the effect of emotional variables to reduce wise decision making when purchasing items and brands.

Alhedhaif, Sheroog; Lele, Upendra; Kaifi, Belal A (2016) Brand Loyalty and Factors Affecting Cosmetics Buying Behavior of Saudi Female Consumers" examined the brand preferences of Saudi consumers for various cosmetics and cosmetics such as skin care products, make-up products, hair care products, perfumes, body care products, enamel nails or similar products. This study also attempts to identify the factors that affect the purchase of cosmetics and the impact of brands on purchasing behavior. The results show that all the above factors have a significant impact on the consumer's purchasing decisions. It was also observed that around $12 \%$ to $20 \%$ of consumers were "brand neutral" in their purchases of cosmetics; other consumers expressed their loyalty to one or more brands.

\section{RESEARCH METHODOLOGY}

\section{Descriptive research}

Descriptive studies include surveys and truth-locating enquiries of different types. In social technology and business studies we quite frequently use the time period the most important function of this technique is that the researcher has no manipulate over the variables; he can handiest file what has happened or what's going on. The methodology may include publication research, interviews, surveys and other research methods, and may include both current and historical information.

\section{Data Collection}

The data is collected from the primary source. Data is collected on the topic of A Study on Brand switching factors of millennial customers on Toiletries.

\section{Sampling Size and Design}

\section{Non Probability Sampling}

Non-sampling sampling is the method of sampling where the researcher selects the samples based on the researcher's autonomy instead of random selection. The sample is not a proportion of the population

\section{Design}

A sample of a hundred respondents became the primary source of data. For the determination of the current study, a relevant model of the population was a selection of on the basis of "CONVENIENT SAMPLING", where the data is collected from the known group of people.

\section{DATA ANALYSIS AND INTERPRETATION}

\section{Kruskal-wallis test}

\section{Hypothesis}

$\mathrm{H}_{0}$ : There is no significant difference among the age group of the respondents

$\mathrm{H}_{1}$ : There is significant difference among the age group of the respondents

\begin{tabular}{|l|l|l|l|}
\hline \multirow{4}{*}{ Sum } & Age of the Respondents & N & Mean Rank \\
\hline \multirow{3}{*}{} & $22-26$ & 80 & 47.35 \\
\cline { 2 - 4 } & $26-30$ & 13 & 44.85 \\
\cline { 2 - 4 } & Total & 93 & \\
\cline { 2 - 4 } & &
\end{tabular}

Table 1 Ranks of age of respondents

\section{Interpretation:}

From the above table, the asymptotic significant value across various age group using Kruskal Wallis test .756 which is greater than 0.05 . Thus as per the decision rule accept null hypothesis so there is no significant difference among the age group of the respondents.

\section{Fried man test}

The Friedman test is non-parametric alternative to the unilateral ANOVA with repeated measurements. It is used to test differences between groups when the dependent variable is ordinal. It can also be used for continuous data that has violated the assumptions necessary to run a one way ANOVA with repeated measurements.

\section{Friedman Test Of Influencing Factors}

\section{Hypothesis}

H0: There is no significant difference among various influencing factors (respondents influenced by others, respondents influenced by advertisements, respondents influenced by the money, respondent influenced by the Promotional offers).

H1: There is significant difference among various influencing factors (respondents influenced by others, respondents influenced by advertisements, respondents influenced by the money, respondent influenced by the Promotional offers).

\begin{tabular}{|l|l|}
\hline & Mean Rank \\
\hline Respondents influenced by others & 2.30 \\
$\begin{array}{l}\text { Respondents influenced } \\
\text { advertisements }\end{array}$ & 2.53 \\
Respondents influenced by the money & 2.40 \\
$\begin{array}{l}\text { Respondents influenced by the } \\
\text { Promotional offers }\end{array}$ & 2.79 \\
\hline
\end{tabular}

Table 2 Ranks of influencing factors

\section{Interpretation:}

From the above table, the asymptotic value for the influencing factors using Friedman test $-\mathrm{K}$ related samples shows a value of .011 which is greater than 0.05.thus as per the decision rule accept the null hypothesis. There is no significant difference among the various influencing factors. Thus the various influencing factors are respondents influenced by the Promotional offers (2.79), respondents influenced by advertisements (2.53), respondents influenced by the money (2.40), respondents influenced by others (2.30). 


\section{Friedman test of Brand switching factors}

Hypothesis:

$\mathrm{H}_{0}$ : There is no significant difference among various factors (Price is the factor for brand switching, Quality is the reason for brand switching, Image is the reason for brand switching, Satisfaction level is the reason for brand switching) used in interpretation of Brand switching factors.

$\mathrm{H}_{1}$ : There is significant difference among various factors (Price is the factor for brand switching, Quality is the reason for brand switching, Image is the reason for brand switching, Satisfaction level is the reason for brand switching) used in interpretation of brand switching factors.

\begin{tabular}{l|l|l|}
\hline & Mean Rank \\
\hline Price is the factor for brand & 2.45 \\
switching \\
Quality is the reason for brand \\
switching \\
Image is the reason for brand \\
$\begin{array}{l}\text { Switching } \\
\text { Satisfaction level is the reason }\end{array}$ \\
for brand switching
\end{tabular}

Table 3 Rank of Brand switching factors.

\section{Interpretation:}

From the above table, the asymptotic value for the influencing factors using Friedman test $-\mathrm{K}$ related samples shows a value of .760 which is greater than 0.05 thus, as per the decision rule accept the null hypothesis. There is no significant difference among the various brand switching factors. Thus the various influencing factors are respondents influenced by the Image is the reason for brand switching (2.58), respondents Satisfaction level is the reason for rand switching(2.53), Price is the factor for brand switching(2.45), Quality is the reason for brand switching(2.44).

\section{Friedman Test Of Satisfaction Factors}

\section{Hypothesis}

$\mathrm{H}_{0}$ : There is no significant difference among various factors (Overall satisfaction of the respondents, Respondents suggest the products to others, Availability of the products is adequate, Experience of the respondents) used in interpretation of satisfaction factors of the respondents.

$\mathrm{H}_{1}$ : There is a significant difference among various factors (Overall satisfaction of the respondents, Respondents suggest the products to others, Availability of the products is adequate, Experience of the respondents) used in interpretation of satisfaction factors of the respondents.

\begin{tabular}{|l|l|}
\hline $\begin{array}{l}\text { Overall satisfaction of the } \\
\text { respondents }\end{array}$ & Mean Rank \\
$\begin{array}{l}\text { Respondents suggest the products } \\
\text { to others } \\
\text { Availability of the products is } \\
\text { adequate }\end{array}$ & 2.22 \\
$\begin{array}{l}\text { Experience of the respondents } \\
\text { ade }\end{array}$ & 3.34 \\
\hline
\end{tabular}

Table 4 Rank table of Satisfaction factors

Interpretation
From table 4, the asymptotic value for the influencing factors using Friedman test $-\mathrm{K}$ related samples shows a value of .000 which is lesser than 0.05 thus, as per the decision rule accept the alternate hypothesis. There is a significant difference among the various satisfaction factors. Thus the various satisfaction factors are Experience of the respondents (3.34), Availability of the products is adequate (2.65), and Respondents suggest the products to others (2.45), Overall satisfaction of the respondents (1.80).

\section{FINDINGS \& RESULTS}

\section{Percentage analysis}

- $\quad 80 \%$ of respondents were aged between 22 to 26 .

- $\quad 78 \%$ of respondents were studying Postgraduate.

- $\quad 59 \%$ of respondents were from nuclear family.

- $49 \%$ of respondent's annual income was above 4

lakh.

- $36 \%$ of respondents used to buy the products like soap, shampoo, toothpaste, toothbrush, perfume, razor.

- $63 \%$ of respondents buy the product as per their need.

- $68 \%$ of respondents spends Rs. 1,000 to Rs.2,000 for buying products.

- $75 \%$ of respondents not frequently trying new products introduced in the market.

- $\quad 52 \%$ of respondents looks for quantity while make their purchasing decision.

- $51 \%$ of respondents would like to purchase the products through online.

- $60 \%$ of respondents agreed that they were influence by other people.

- $47 \%$ of respondents agreed that they were influenced by the advertisements.

- $40 \%$ of respondents agreed that they were influenced by the money factor.

- $\quad 30 \%$ of respondents strongly agreed that they were influenced by the promotional offers.

- $52 \%$ of respondents were influenced by their relatives.

- $\quad 37 \%$ of respondents were influenced by the free samples.

- $\quad 50 \%$ of respondents agreed the statement that price is the factor for brand switching.

- $\quad 49 \%$ of respondents strongly agreed that the quality is the main factor for brand switching.

- $45 \%$ of respondents agreed that brand image is the reason for brand switching.

- $54 \%$ of respondents strongly agreed that satisfaction level is also influenced them for brand switching.

- $\quad 57 \%$ of respondents agreed that they were satisfied by the products they are using at present.

- $\quad 49 \%$ of respondents neither agreed nor disagreed to the statement that they will suggest their products to others.

- $56 \%$ of respondents neither agreed nor disagreed to

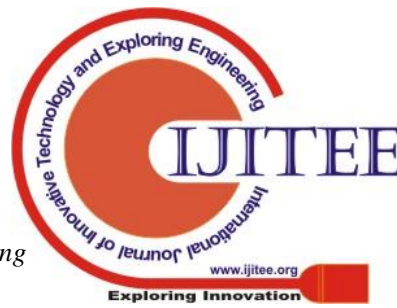


the statement that the availability of their products was adequate.

- $\quad 58 \%$ of respondents didn't face any bad experience with the product that they are using at present.

\section{Kruskal-Wallis test}

- $\quad$ The Kruskal-Wallis test results reveals that there is no significance difference between the responses of the respondent's age group.

\section{Friedman test}

- The Friedman test results reveals that there is no significant difference among the various influencing factors and the factor promotional offers influence the respondents the most.

- The Friedman test results reveals that there is no significant difference among the various brand switching factors and the brand image is the highest among these factors.

- The Friedman test result reveals that there is a significant difference among the various satisfaction factors.

\section{SUGGESTIONS}

- $\quad$ The customers were highly influenced by the TV advertisements so the marketers can concentrate more on other advertisement modes like print media etc.

- $\quad$ The customer mostly prefers online shopping but they are not satisfied by the availability of the products, so the marketers can increase the availability of the products online.

- The customers expecting more promotional offers from the marketers, so the marketers can increase the promotional techniques preferably run a promotional campaign etc.

- The customer looks the brand image as an important factor in buying a product, so the marketer can increase the image of their brand to acquire new customers.

\section{CONCLUSION}

This study is conducted to investigate whether the influencing factors influence the customers to make a purchase and also to check what brand switching factor influence the customers to make a purchase. And the results derived says that the influencing factors like price, quality, advertisements plays an vital role in influencing the customers and also the respondents were influenced by the family members, friends and peers. It is also found that the respondents will be loyal to the brand when the brand meets the satisfaction level of the respondents. And when it happens the respondents were ready to suggest the brand to others and influence them to try the brand.

\section{REFERENCES}

1. Alhedhaif, Sheroog; Lele, Upendra; Kaifi, Belal A, (Mar 2016): Brand Loyalty and Factors Affecting Cosmetics Buying Behavior of Saudi Female Consumers. Journal of Business Studies Quarterly: Antioch Vol. 7, Iss. 3 2438.

2. Babayev, Najaf. 2011 "Emotion-based marketing and its impact on consumer decision making": International
Journal on Global Business Management \& Research; Chennai Vol. 7, Iss. 3, (Aug 2018): 31-43.

3. Guthrie, Michelle; Hye-Shin, Kim; Jung, Jaehee 2008: The effects of facial image and cosmetic usage on perceptions of brand personality: Journal of Fashion Marketing and Management; Bradford Vol. 12, Iss. 2: 164-181.

4. Latuszynska, Malgorzata; Furaiji, Fatimah; Wawrzyniak, Agata.2012: An Empirical Study of the Factors Influencing Consumer Behavior in the Electric Appliances Market: Contemporary Economics; Warsaw Vol. 6, Iss. 3:76.

5. Paul, Justin; Sankaranarayanan, Koloth G; Mekoth, Nandakumar (2015) "Consumer satisfaction in retail stores: theory and implications" International Journal of Consumer Studies ; Oxford Vol. 40 Iss. 6(Nov 2016): 635-642.

6. Rieg, Denise Luciana ; Scramim, Fernando Cezar Leandro ; da Silva, Elaine Paola ; Rufino, Fabiana Alves (2018): The Influence of the Seller's Performance on the Consumer Purchase Of Clothes and Personal Care, Toiletries and Cosmetics Products Independent Journal of Management \& Production; Sao Paulo Vol. 9, Iss.2 507-525.

7. Rajagopal 2007: Buying decisions towards organic products: an analysis of customer value and brand drivers: Rajagopal. International Journal of Emerging Markets: Bradford Vol. 2, Iss. 3: 236-251.

8. Senthilkumar, K 2018: The Influence of Emotional Factors in the Purchase of Children Products and Brands: International Journal of Education and Management Engineering; Hong Kong Vol. 8, Iss. 5: 18.

9. Shukla, Paurav 2009 "Impact of contextual factors, brand loyalty and brand switching on purchase decisions" The Journal of Consumer Marketing;Santa Barbara Vol. 26, Iss. 5: 348-357.

10. Srivastava, Neha; Dash, Satya Bhushan; Mookerjee, Amit 2015: Antecedents and moderators of brand trust in the context of baby care toiletries: The Journal of Consumer Marketing; Santa Barbara Vol. 32, Iss. 5, (2015): 328-340

11. Sudhakar, A; Rani, T Suchitra 2013: Empirical Investigation of Demographic Determinants in Consumers' Preference of Personal Care Products: Journal of Management Research; New Delhi Vol. 13, Iss. 2, 89-104.

12. Tomko, Paul R 2012 "Understanding the factors affecting the influence of children on their parents' total purchases"Capella University, ProQuest Dissertations Publishing, 2012. 3505757.

13. Ullah, G M Shafayet; Prince, Panuel Rozario,(Mar 2012): Factors Influencing the Bangladeshi Consumers' Purchase Decision Regarding Fast Moving Consumer Goods: An Exploratory Study: IUP Journal of Brand Management; Hyderabad Vol. 9, Iss: 7-27.

14. Vanaja Menon (2012) "Multi-culture consumer behaviour in the Abu Dhabi markets" Education, Business and Society: Contemporary Middle Eastern Issues; Bingley Vol. 6, Iss. 1(2013): 42-54.

15. Vaishnavi, G; Ganesh, S K G; Thomas, Charlie V. (2014) "Environmental Behavior of Consumers vis-à-vis Customer Relationship, Trust and Loyalty: Some Research Reflections and Organisational Practices" 